\title{
Energy Consumption Analysis and Diagnosis of Heating System
}

\author{
Environmental United (Beijing) Certification Center Co., Ltd., Beijing City, China
}

\section{XX Community Profile}

\subsection{Community Basic Situations}

XX Community is located at West Beitucheng Road, Haidian District, Beijing, China, which was completed in 1982. The boiler house, pump house and heat exchange station are set for the heating system in the community, to provide the heating service for the residential building, and the heating area is $308,000 \mathrm{~m} 2$ in total. The property management company is responsible for the operation and maintenance of the heating equipment.

1.2 XX Community Heating Energy Consumption Analysis

Refer to Table 1 for the collection of three historical heating season energy consumption of XX Community.

\begin{tabular}{|c|c|c|c|}
\hline $\begin{array}{c}\text { Types of } \\
\text { energy }\end{array}$ & $\begin{array}{c}2008-2009 \\
\text { heating } \\
\text { season }\end{array}$ & $\begin{array}{c}2009-2010 \\
\text { heating } \\
\text { season }\end{array}$ & $\begin{array}{c}2010-2011 \\
\text { heating } \\
\text { season }\end{array}$ \\
\hline $\begin{array}{c}\text { Natural gas } \\
\left(\mathrm{m}^{3}\right)\end{array}$ & $2,207,254$ & $2,900,387$ & $2,479,853$ \\
\hline $\begin{array}{c}\text { Electricity } \\
(\mathrm{kWh})\end{array}$ & 418,100 & 461,100 & 490,400 \\
\hline $\begin{array}{c}\text { Total energy } \\
\text { consumption } \\
\text { (tce) }\end{array}$ & $2,731.65$ & $3,578.61$ & $3,071.56$ \\
\hline
\end{tabular}

Table 1. XX Community Historical Heating Season Energy Consumption

The heating season consumes 2.4798 million $\mathrm{m}^{3}$ of natural gas, the power was $490,400 \mathrm{kWh}$, equivalent to $3,071.56$ tons of standard coal, and the energy consumption per unit heating area was $9.97 \mathrm{kgce} / \mathrm{m} 2$ from 2010 to 2011 in XX Community through the accounting.

Abstract: The gas boiler house is responsible for heating $308,000 \mathrm{~m} 2$ of residents in the community, and the historical heating energy consumption reached 3,000 tons of standard coal in 2012. The heating energy consumption index in this community is higher than that of heating energy consumption index in other residential communities. The heating system in this community is tested and analyzed comprehensively in this paper. The three aspects of heating system heat source, pipe network transmission and distribution and thermal user are combed and analyzed in this paper, to look for the energy-saving potential of each link.

It is found that the exhaust gas temperature is $175^{\circ} \mathrm{C}$ through the test of thermal efficiency of 2 \# boiler in XX Community, and the heat loss of exhaust gas is higher. Meanwhile, it is found that the exhaust gas temperature is too high in all boilers through checking the operation record. It is found that the system water recharge is larger and the problems of leaking and aging thermal insulation layer and pipeline appear in the heating network through operation record analysis and on-site inspection. The analysis shows that there is a problem of hydraulic imbalance through the on-site test on the wall temperature of the supply pipe of the hot water supply wells in the residential buildings near, middle and far-ends.

Analyze the problem existing in the heating system in XX Community, and put forward some corresponding energy saving technical proposals, such as flue gas condensing waste heat recovery, hydraulic balance adjustment and pipeline insulation improvement according to on-site survey and analysis; meanwhile, estimate the energy saving effect and the investment payback period.

It is expected to realize the energy saving 728.72 tce and energy saving benefit of 1.4415 million yuan through three measures for energy saving and technical transformation. Estimated investment cost is 3.16 million yuan.

key words: Heating system;

Energy-saving potential;

Condensing waste heat recovery and hydraulic balance

Published online: 30th Sept, 2017 


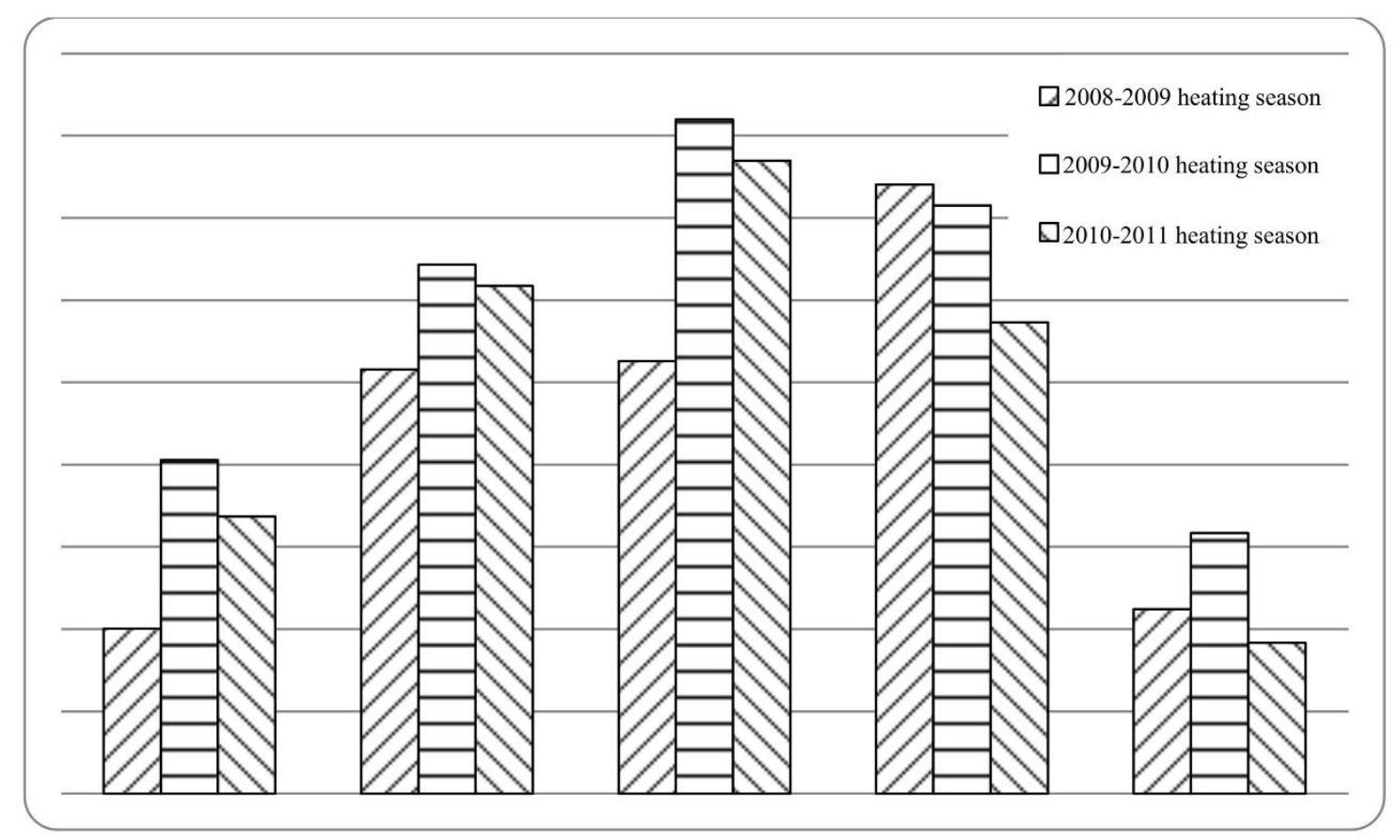

Figure 1. Comparison of Gas Consumption in Heating Season

From the Figure 1, we can see the natural gas consumption in heating season is higher than that of the other two heating seasons from 2009 to 2010. The main reason analysis is that the climate is abnormal in the heating season, and the continuous low temperature increases the monthly consumption of natural gas. The early heating and extended heating are reflected in the figure where the natural gas consumption in November and March was much higher than in the other two months. In addition, the heating energy consumption in 2010 is higher than that of heating energy consumption in 2008. The main reason is the heating area increased by $41,000 \mathrm{~m} 2$ in $\mathrm{XX}$ Community in 2010.

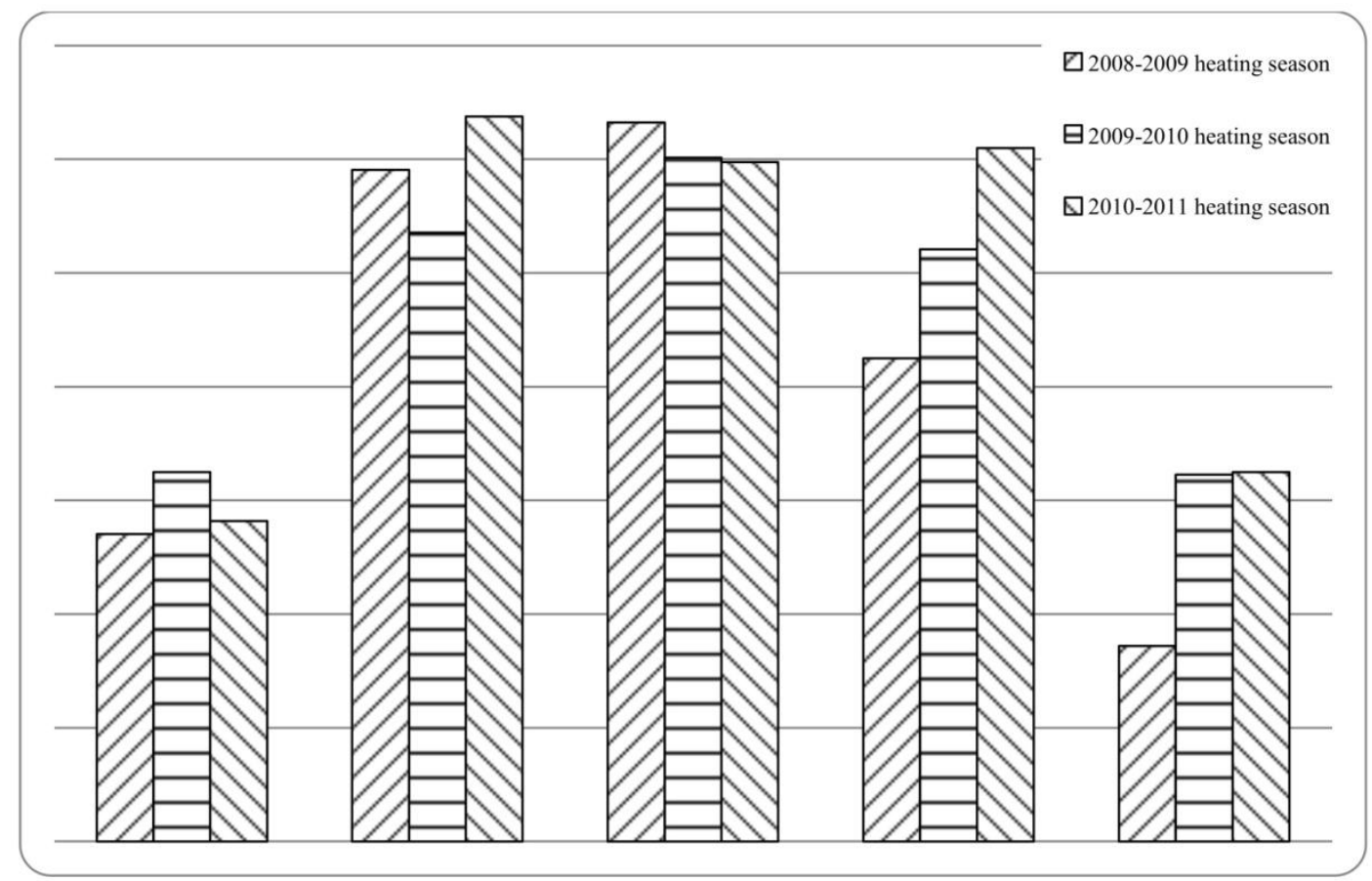

Figure 2. Comparison of Power Consumption in Heating Season 


\subsubsection{Heat source analysis}

8 sets of $2.8 \mathrm{MW}$ gas-fired hot water boilers and auxiliary auxiliaries are set in boiler houses in the community, and refer to Table 2 for the main equipment parameters.

\begin{tabular}{|c|c|c|c|c|}
\hline $\mathrm{S} / \mathrm{N}$ & Equipment name & Equipment model & $\begin{array}{c}\text { Main } \\
\text { parameters }\end{array}$ & Manufacturers \\
\hline 1 & $\begin{array}{c}\text { Gas-fired hot water } \\
\text { boiler }\end{array}$ & $\begin{array}{c}\text { LZS2.80-0.7/95/70-Y(Q)-M } \\
\text { F7 }\end{array}$ & 8 sets, $2.8 \mathrm{MW}$ & $\begin{array}{l}\text { Shandong } \\
\text { Taishan }\end{array}$ \\
\hline 2 & $\begin{array}{c}1 \text { \# Southern district } \\
\text { low pressure circulating } \\
\text { pump }\end{array}$ & ISG(B)200-315(I)A & $\begin{array}{c}374 \mathrm{~m}^{3} / \mathrm{h}, 28 \mathrm{~m} \\
45 \mathrm{~kW}\end{array}$ & $\begin{array}{l}\text { Shandong } \\
\text { Shuanglun }\end{array}$ \\
\hline 3 & $\begin{array}{c}2 \text { \# Southern district } \\
\text { low pressure circulating } \\
\text { pump }\end{array}$ & QPG200R-4000 & $\begin{array}{c}260 \mathrm{~m}^{3} / \mathrm{h}, 32 \mathrm{~m}, \\
37 \mathrm{~kW}\end{array}$ & $\begin{array}{l}\text { Wenzhou } \\
\text { Tsinghua }\end{array}$ \\
\hline 4 & $\begin{array}{c}1 \text { \# Northern district } \\
\text { low pressure circulating } \\
\text { pump }\end{array}$ & ISG(B)200-315(I)A & $\begin{array}{c}374 \mathrm{~m}^{3} / \mathrm{h}, 28 \mathrm{~m} \\
45 \mathrm{~kW}\end{array}$ & $\begin{array}{l}\text { Shandong } \\
\text { Shuanglun }\end{array}$ \\
\hline 5 & $\begin{array}{l}\text { 2\# Northern district low } \\
\text { pressure circulating } \\
\text { pump }\end{array}$ & QPG200R-4000 & $\begin{array}{c}260 \mathrm{~m}^{3} / \mathrm{h}, 32 \mathrm{~m}, \\
37 \mathrm{~kW}\end{array}$ & $\begin{array}{l}\text { Wenzhou } \\
\text { Tsinghua }\end{array}$ \\
\hline 6 & $\begin{array}{l}\text { 1\#high pressure } \\
\text { circulating pump }\end{array}$ & QPG200R-4000 & $\begin{array}{c}260 \mathrm{~m}^{3} / \mathrm{h}, 32 \mathrm{~m}, \\
37 \mathrm{~kW}\end{array}$ & $\begin{array}{l}\text { Wenzhou } \\
\text { Tsinghua }\end{array}$ \\
\hline 7 & $\begin{array}{l}\text { 2\#high pressure } \\
\text { circulating pump }\end{array}$ & QPG200R-4000 & $\begin{array}{c}260 \mathrm{~m}^{3} / \mathrm{h}, 32 \mathrm{~m}, \\
37 \mathrm{~kW}\end{array}$ & $\begin{array}{l}\text { Wenzhou } \\
\text { Tsinghua }\end{array}$ \\
\hline 8 & $\begin{array}{c}\text { 1\#boiler circulating } \\
\text { pump }\end{array}$ & QPG200R-260 & $\begin{array}{c}320 \mathrm{~m}^{3} / \mathrm{h}, 20 \mathrm{~m}, \\
30 \mathrm{~kW}\end{array}$ & $\begin{array}{l}\text { Wenzhou } \\
\text { Tsinghua }\end{array}$ \\
\hline 9 & $\begin{array}{l}\text { 2\#boiler circulating } \\
\text { pump }\end{array}$ & QPG200R-260 & $\begin{array}{c}320 \mathrm{~m}^{3} / \mathrm{h}, 20 \mathrm{~m}, \\
30 \mathrm{~kW}\end{array}$ & $\begin{array}{l}\text { Wenzhou } \\
\text { Tsinghua }\end{array}$ \\
\hline 10 & $\begin{array}{l}\text { 3\#boiler circulating } \\
\text { pump }\end{array}$ & QPG150R-260 & $\begin{array}{c}200 \mathrm{~m}^{3} / \mathrm{h}, 20 \mathrm{~m} \\
18.5 \mathrm{~kW}\end{array}$ & $\begin{array}{l}\text { Wenzhou } \\
\text { Tsinghua }\end{array}$ \\
\hline 11 & $\begin{array}{l}\text { 4\#boiler circulating } \\
\text { pump }\end{array}$ & QPG150R-260 & $\begin{array}{c}200 \mathrm{~m}^{3} / \mathrm{h}, 20 \mathrm{~m}, \\
18.5 \mathrm{~kW}\end{array}$ & $\begin{array}{l}\text { Wenzhou } \\
\text { Tsinghua }\end{array}$ \\
\hline 12 & $\begin{array}{l}\text { Plate-type heat } \\
\text { exchanger }\end{array}$ & BRX0.6EH & 6 sets, $100 \mathrm{~m}^{2}$ & $\begin{array}{l}\text { Yungtay } \\
\text { Engineering }\end{array}$ \\
\hline
\end{tabular}

Table 2. Main Equipment List of XX Boiler House 
The community heating mode is the inter supply, and the heating system is shown in Figure 3, 6 block plate heat exchangers are set in the boiler house, and the secondary water and boiler primary water heat exchange each other through the heat exchanger. In the heating season, the firemen take manual start and stop control of the boiler in operation according to outdoor temperature and return water temperature of secondary water supply, and the boiler won't be adjusted after operation. The power consumption of the boiler house was $472,900 \mathrm{kWh}$ in 2013 . The transmission coefficient of heating system is calculated 49.21 .

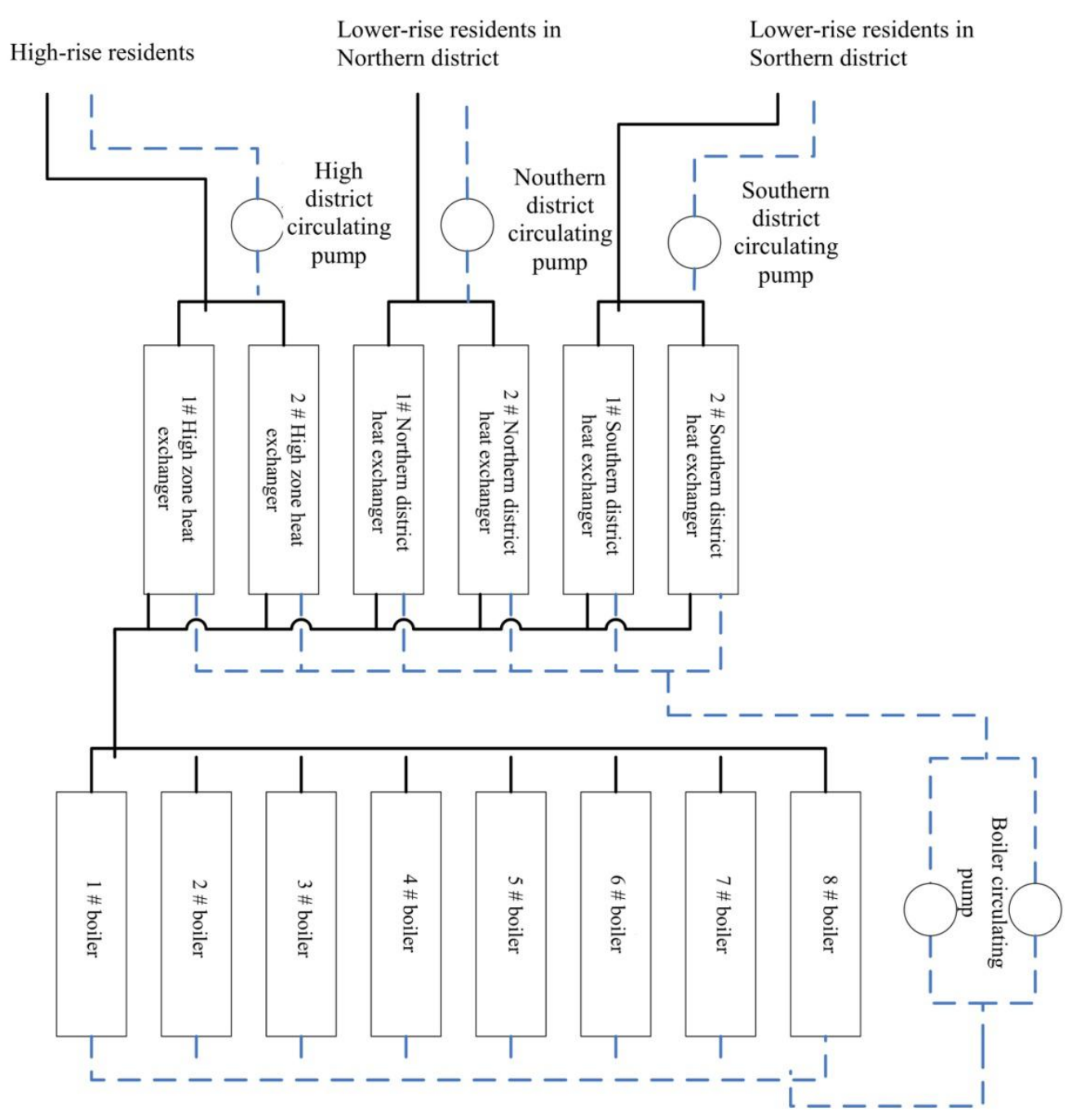

Figure 3. Schematic Diagram of Heating System in XX Community 
From the Figure 1, we can see the natural gas consumption in heating season is higher than that of the other two heating seasons from 2009 to 2010. The main reason analysis is that the climate is abnormal in the heating season, and the continuous low temperature increases the monthly consumption of natural gas. The early heating and extended heating are reflected in the figure where the natural gas consumption in November and March was much higher than in the other two months. In addition, the heating energy consumption in 2010 is higher than that of heating energy consumption in 2008. The main reason is the heating area increased by $41,000 \mathrm{~m} 2$ in $\mathrm{XX}$ Community in 2010.

\begin{tabular}{|c|c|c|c|}
\hline Project & Unit & Test results & Contrast index \\
\hline Thermal efficiency $\eta$ & $\%$ & 87.59 & $\geq 90$ \\
\hline Exhaust gas temperature tpy & ${ }^{\circ} \mathrm{C}$ & 175 & $\leq 160$ \\
\hline Air coefficient $\alpha$ & & 1.17 & $\leq 0.02$ \\
\hline CO content: & $\%$ & 0.001 & $/$ \\
\hline Boiler outlet water temperature & ${ }^{\circ} \mathrm{C}$ & 52.3 & $/$ \\
\hline Heat loss of exhaust gas & $\%$ & 7.32 & $/$ \\
\hline Heat loss due to radiation & $\%$ & 3.10 & $/$ \\
\hline Heat loss due to mechanical incomplete & $\%$ & 0.004 & \\
\hline combustion & & & \\
\hline
\end{tabular}

Table 3. Indicator Comparison of XX Community Boiler Measurement Result

From the above table, we can see that $2 \#$ boiler efficiency in the boiler house of $\mathrm{XX}$ Community is lower than the control index, and the main cause analysis is the excessive heat loss of exhaust gas. The heat loss of exhaust gas of the boiler is $7.32 \%$, accounting for $70.24 \%$ of the sum of the boiler heat loss. The excessive exhaust gas temperature causes a large amount of physical heat to be taken away by the smoke, which increases the natural gas consumption. Thus, the reasonable recovery and utilization of boiler flue gas heat and the improvement of exchange effect of boiler heat will effectively reduce the heat loss of exhaust gas and increase the boiler efficiency. In addition, pay attention to reducing the heat dissipation of the boiler, improve the insulation performance of the furnace body and reduce the heat loss of the boiler.

1.2.2 Analysis and evaluation of pipe network transmission and thermal users

The secondary heat pipe network in XX Community consists of three main loop, including high pressure loop, southern low pressure loop and north community low pressure loop. The perlite is adopted for the pipe insulation originally, and the perlite is changed with polyurethane foam for the insulation in a few pipes during the maintenance process later. At present, the frequency conversion equipment has been installed for the secondary circulating pump, and the one big one and small parallel operation mode is adopted for the primary circulating pump. The heating pipe network in the community is shown in Figure 4. 


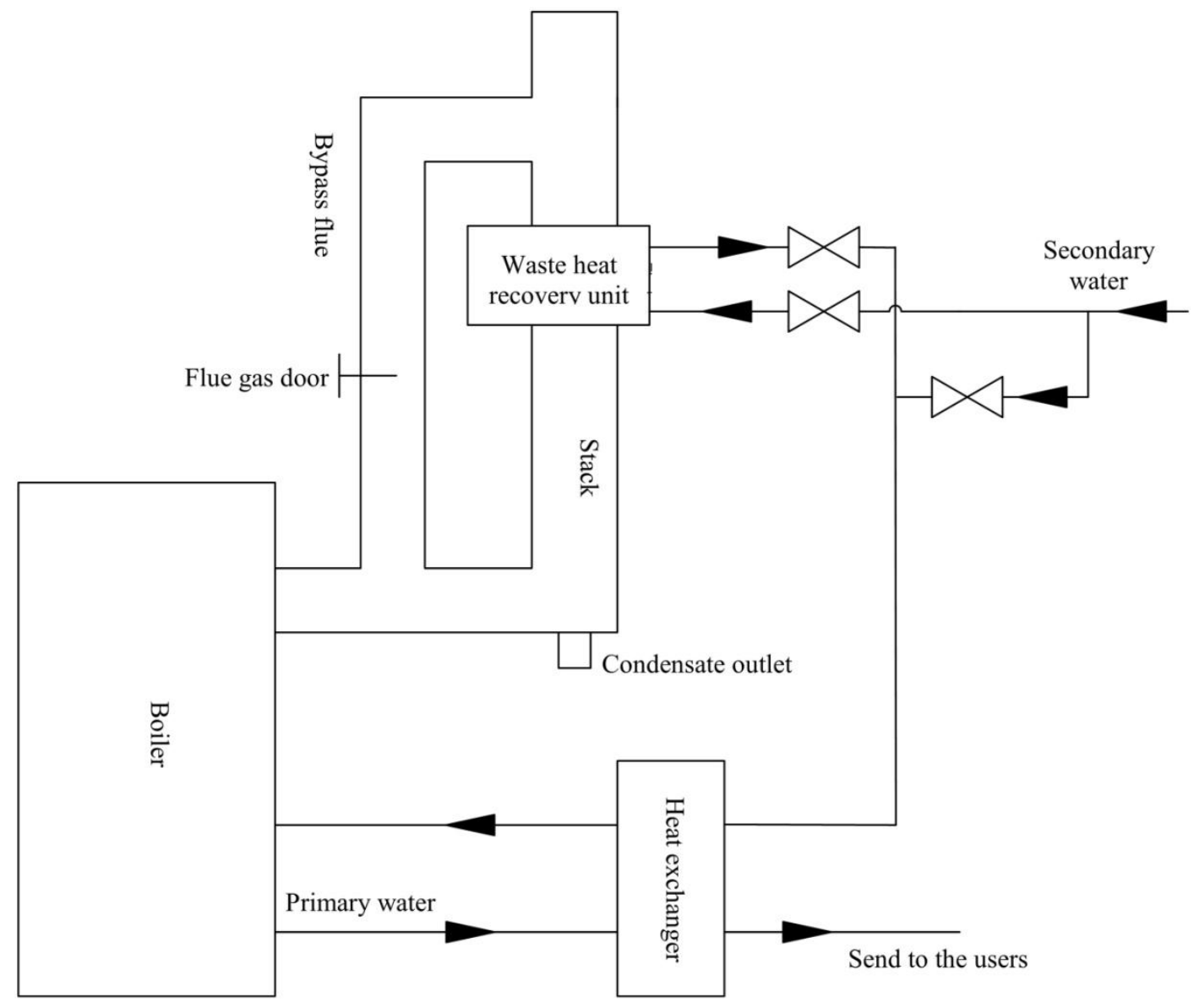

Figure 4. Flue Gas Condensing Waste Heat Recovery and Reconstruction

The community was completed in 1982, and the residence is divided into four regions. There are 12 residential buildings in 1 \# garden, and 8 residential buildings in $2 \#, 3$ \# and 4 \# gardens. There are about 3,600 residents. Residential buildings are mainly divided into high-rise and multi-storey buildings, and the number of buildings is concentrated on the 6th floor,14th floor and 18th floor. The brick concrete structure is adopted for multi-storey construction, while the steel-concrete frame structure is adopted for the high-rise construction. The typical construc-tion information is shown in Table 4. The insulation is not adopted for the exterior walls of the residents themselves with steel window frames with single layer glass, and the terminal radiator is made of cast iron radiators. The heat metering has not been realized according to the common heating area fee. Meanwhile, the thermal user flow adjustment has not been realized with the collusion form. 


\begin{tabular}{|c|c|c|c|c|c|}
\hline & Building No. & $\begin{array}{c}\text { Number of } \\
\text { stories of } \\
\text { building }\end{array}$ & $\begin{array}{c}\text { Constructio } \\
\mathrm{n} \text { area/m }\end{array}$ & $\begin{array}{l}\text { Heating } \\
\text { area/ } \mathrm{m}^{2}\end{array}$ & $\begin{array}{l}\text { Architecture } \\
\text { structure form }\end{array}$ \\
\hline \multirow{5}{*}{1 \# garden } & 1 \# building & 13 & 21,962 & 18,469 & steel-concrete \\
\hline & 2 \# building & 6 & 4,262 & 4,262 & brick-concrete \\
\hline & 3 \# building & 6 & 3,162 & 3,162 & brick-concrete \\
\hline & 7 \# building & 6 & 3,197 & 3,197 & brick-concrete \\
\hline & 9 \# building & 6 & 4,203 & 4,203 & brick-concrete \\
\hline \multirow{2}{*}{2 \# garden } & 1 \# building & 14 & 17,154 & 15,384 & steel-concrete \\
\hline & 2 \# building & 6 & 3,208 & 3,208 & brick-concrete \\
\hline \multirow{5}{*}{3 \# garden } & 1 \# building & 18 & 9,249 & 8,528 & steel-concrete \\
\hline & 4 \# building & 14 & 12,477 & 12,477 & steel-concrete \\
\hline & 5 \# building & 6 & $4,148.22$ & $4,148.22$ & brick-concrete \\
\hline & 6 \# building & 6 & 4,262 & 4,262 & brick-concrete \\
\hline & 7 \# building & 6 & 4,250 & 4,250 & brick-concrete \\
\hline \multirow{2}{*}{4 \# garden } & 1 \# building & 18 & 9,429 & 8,528 & steel-concrete \\
\hline & 4 \# building & 6 & 4,262 & 4,262 & brick-concrete \\
\hline
\end{tabular}

Table 4. Typical Construction Information List of XX Community

The boiler operation record is selected as the basis for data analysis of boiler system from November 2010 to March 2011 in this paper, and the Table 5 is obtained through the calculation and arrangement of the boiler operation record. 


\begin{tabular}{|c|c|c|c|c|c|c|}
\hline $\begin{array}{l}\text { Circulating } \\
\text { water } \\
\text { system }\end{array}$ & Parameter & $\begin{array}{c}\text { November } \\
2010\end{array}$ & $\begin{array}{c}\text { December } \\
2010\end{array}$ & $\begin{array}{c}\text { January } \\
2011\end{array}$ & $\begin{array}{c}\text { February } \\
2011\end{array}$ & $\begin{array}{l}\text { March } \\
2011\end{array}$ \\
\hline \multirow{3}{*}{ Primary test } & $\begin{array}{c}\text { Average supply water } \\
\text { temperature }\left({ }^{\circ} \mathrm{C}\right)\end{array}$ & 42 & 44 & 54 & 53 & 52 \\
\hline & $\begin{array}{c}\text { Average return water } \\
\text { temperature }\left({ }^{\circ} \mathrm{C}\right)\end{array}$ & 32 & 34 & 46 & 45 & 44 \\
\hline & $\begin{array}{c}\text { Mean temperature } \\
\text { difference }\left({ }^{\circ} \mathrm{C}\right)\end{array}$ & 10 & 10 & 8 & 8 & 8 \\
\hline \multirow{5}{*}{$\begin{array}{c}\text { Secondary } \\
\text { test } \\
\text { high-rise } \\
\text { loop }\end{array}$} & $\begin{array}{c}\text { Average supply water } \\
\text { pressure (MPa) }\end{array}$ & 0.72 & 0.72 & 0.72 & 0.72 & 0.72 \\
\hline & $\begin{array}{c}\text { Average return water } \\
\text { pressure (MPa) }\end{array}$ & 0.54 & 0.54 & 0.54 & 0.54 & 0.54 \\
\hline & $\begin{array}{c}\text { Average supply water } \\
\text { temperature }\left({ }^{\circ} \mathrm{C}\right)\end{array}$ & 40 & 41 & 48 & 47 & 46 \\
\hline & $\begin{array}{c}\text { Average return water } \\
\text { temperature }\left({ }^{\circ} \mathrm{C}\right)\end{array}$ & 38 & 39 & 44 & 43 & 40 \\
\hline & $\begin{array}{c}\text { Mean temperature } \\
\text { difference }\left({ }^{\circ} \mathrm{C}\right)\end{array}$ & 2 & 2 & 4 & 4 & 6 \\
\hline \multirow{5}{*}{$\begin{array}{c}\text { Secondary } \\
\text { test } \\
\text { low-rise } \\
\text { loop }\end{array}$} & $\begin{array}{c}\text { Average supply water } \\
\text { pressure (MPa) }\end{array}$ & 0.38 & 0.38 & 0.38 & 0.38 & 0.38 \\
\hline & $\begin{array}{c}\text { Average return water } \\
\text { pressure (MPa) }\end{array}$ & 0.24 & 0.24 & 0.24 & 0.24 & 0.24 \\
\hline & $\begin{array}{c}\text { Average supply water } \\
\text { temperature }\left({ }^{\circ} \mathrm{C}\right)\end{array}$ & 41 & 43 & 48 & 47 & 45 \\
\hline & $\begin{array}{c}\text { Average return water } \\
\text { temperature }\left({ }^{\circ} \mathrm{C}\right)\end{array}$ & 38 & 40 & 44 & 43 & 39 \\
\hline & $\begin{array}{c}\text { Mean temperature } \\
\text { difference }\left({ }^{\circ} \mathrm{C}\right)\end{array}$ & 3 & 3 & 4 & 4 & 6 \\
\hline \multicolumn{2}{|c|}{ verage water recharge $(\mathrm{t})$} & 47 & 34 & 25 & 9 & 25 \\
\hline
\end{tabular}

Table 5. Boiler Operation Record and Arrangement List in Heating Season from 2010 to 2011

From the operation record, we can see that in the early stage of boiler house heating in XX Community, the water temperature difference between the high-pressure circulation water supply system and the water supply system is maintained at about $2^{\circ} \mathrm{C}$, and about
$4{ }^{\circ} \mathrm{C}$ during the cold period. The water temperature difference between the low pressure cycle and the water supply is maintained from $4{ }^{\circ} \mathrm{C}$ to $6{ }^{\circ} \mathrm{C}$ during the heating season. The system temperature is not large between early and late heating stage and cold period, and and there is a big gap compared with the average temperature difference between the supply and return water of the heating system. Thus, the audit team thinks that the "Large flow and small temperature difference" operation mode is adopted as the boiler house heating mode. The 
average daily water supply of the secondary network in the boiler house of the community is about 25 tons. The leaking phenomena happen occasionally due to the pipe network aging according to the on-site communication and under-standing.

The boiler system was tested on
December 16, 2011. The main test object is the temperature of inlet and outlet of plate heat exchanger, and the result is shown in Table 6. The infrared temperature instrument is used to measure the wall temperature of the total supply and return pipe of hot water in some residential buildings. The measurement method is: Choose a straight pipe section, open the insulation layer, perform simple sanding of the pipe surface, and use the thermometer to record the data above $1 \mathrm{~m}$ of the measuring point within the range. The recorded data are shown in the Table 7.

\begin{tabular}{|c|c|c|c|c|c|}
\hline \multirow{2}{*}{$\mathrm{S} / \mathrm{N}$} & \multirow{2}{*}{ Name } & \multicolumn{2}{|c|}{ Primary test temperature $\left({ }^{\circ} \mathrm{C}\right)$} & \multicolumn{2}{|c|}{ Secondary test temperature $\left({ }^{\circ} \mathrm{C}\right)$} \\
\hline & & Inlet & Outlet & Inlet & Outlet \\
\hline 1 & $\begin{array}{l}1 \text { \# High zone } \\
\text { heat exchanger }\end{array}$ & 58 & 43 & 41 & 48 \\
\hline 2 & $\begin{array}{l}2 \text { \# High zone } \\
\text { heat exchanger }\end{array}$ & 58 & 41 & 41 & 48 \\
\hline 3 & $\begin{array}{l}1 \text { \# Northern } \\
\text { district heat } \\
\text { exchanger }\end{array}$ & 58 & 46 & 45 & 49 \\
\hline 4 & $\begin{array}{l}2 \text { \# Northern } \\
\text { district heat } \\
\text { exchanger }\end{array}$ & 58 & 46 & 45 & 49 \\
\hline 5 & $\begin{array}{l}1 \text { \# Southern } \\
\text { district heat } \\
\text { exchanger }\end{array}$ & 58 & 45 & 44 & 48 \\
\hline 6 & $\begin{array}{l}2 \text { \# Southern } \\
\text { district heat } \\
\text { exchanger }\end{array}$ & 58 & 45 & 44 & 48 \\
\hline
\end{tabular}

Table 6. Boiler House Temperature Test Record 


\begin{tabular}{|c|c|c|c|c|c|c|}
\hline$S / N$ & Position & Building No. & $\begin{array}{l}\text { Building } \\
\text { type }\end{array}$ & $\begin{array}{c}\text { Supply water } \\
\text { temperature/ } \\
{ }^{\circ} \mathrm{C}\end{array}$ & $\begin{array}{c}\text { Return water } \\
\text { temperature/ } \\
{ }^{\circ} \mathrm{C}\end{array}$ & $\begin{array}{l}\text { Temperature } \\
\text { difference } /{ }^{\circ} \mathrm{C}\end{array}$ \\
\hline 1 & $\begin{array}{l}\text { High loop } \\
\text { far-end }\end{array}$ & $\begin{array}{c}\text { Winter Jasmine } \\
\text { Garden } 1 \text { \# building }\end{array}$ & $\begin{array}{c}\text { Small } \\
\text { high-rise }\end{array}$ & 41 & 35 & 6 \\
\hline 2 & $\begin{array}{l}\text { South loop } \\
\text { far-end }\end{array}$ & $\begin{array}{c}\text { Winter Jasmine } \\
\text { Garden } 2 \text { \# building }\end{array}$ & $\begin{array}{c}\text { Multi-st } \\
\text { orey }\end{array}$ & 44 & 40 & 4 \\
\hline 3 & $\begin{array}{l}\text { High loop } \\
\text { near-end }\end{array}$ & $\begin{array}{c}\text { Winter Jasmine } \\
\text { Garden 8\#building }\end{array}$ & High-rise & 44 & $\begin{array}{l}\text { It cannot be } \\
\text { measured }\end{array}$ & / \\
\hline 4 & $\begin{array}{l}\text { South loop } \\
\text { far-end }\end{array}$ & $\begin{array}{l}\text { Summer Garden } \\
\text { 5\#building }\end{array}$ & $\begin{array}{c}\text { Multi-st } \\
\text { orey }\end{array}$ & 44 & 37 & 7 \\
\hline 5 & $\begin{array}{l}\text { South loop } \\
\text { middle-en } \\
\text { d }\end{array}$ & $\begin{array}{l}\text { Summer Garden } \\
\text { 7\#building }\end{array}$ & $\begin{array}{c}\text { Multi-st } \\
\text { orey }\end{array}$ & 44 & 38 & 6 \\
\hline 6 & $\begin{array}{l}\text { North loop } \\
\text { far-end }\end{array}$ & $\begin{array}{c}\text { Lang Autumn } \\
\text { Garden 6\#building }\end{array}$ & $\begin{array}{c}\text { Multi-st } \\
\text { orey }\end{array}$ & 44 & 40 & 4 \\
\hline 7 & $\begin{array}{l}\text { North loop } \\
\text { near-end }\end{array}$ & $\begin{array}{c}\text { Lang Autumn } \\
\text { Garden 8\#building }\end{array}$ & $\begin{array}{c}\text { Multi-st } \\
\text { orey }\end{array}$ & 45 & 37 & 8 \\
\hline 8 & $\begin{array}{l}\text { High loop } \\
\text { far-end }\end{array}$ & $\begin{array}{c}\text { Sunny Winter } \\
\text { Garden 1\#building }\end{array}$ & High-rise & 46 & 39 & 7 \\
\hline 9 & $\begin{array}{l}\text { North loop } \\
\text { far-end }\end{array}$ & $\begin{array}{c}\text { Sunny Winter } \\
\text { Garden 5\#building }\end{array}$ & $\begin{array}{c}\text { Multi-st } \\
\text { orey }\end{array}$ & 42 & 37 & 5 \\
\hline
\end{tabular}

Table 7. Temperature Test of the Total Supply and Return Pipe in Some Residential Buildings (outdoor temperature $-5^{\circ} \mathrm{C}$ )

The final analysis of the heat supply network heat maladjustment is caused by uneven flow allocation, that is, the maladjustment is caused by the hydraulic imbalance. The hydraulic imbalance can be reflected from the users' temperature difference between the back and forth. If the system flow distribution is matched with the required heating quantity, the water temperature difference shall be basically the same everywhere. $v$ According to the test result, the supply water temperature difference between the buildings is different with the maximum temperature difference $8{ }^{\circ} \mathrm{C}$ and the minimum $4^{\circ} \mathrm{C}$; according to the calculation result, the hydraulic imbalance is obvious, which will cause $10 \%$ of energy waste at least, so we shall pay more attention to it.

From the Table 1-6 and Table 1-7, we can see that the average supply water temperature in all buildings is about $4{ }^{\circ} \mathrm{C}$ from the total supply water temperature with the maximum value $7^{\circ} \mathrm{C}$. On one hand, it is possible that the infrared thermometer itself has measurement errors; on the other hand, it is possible that old heating pipe network, pipeline aging, heating pipe insulation and pipe ditch water shedding phenomenon, and not ideal insulation effect in this community. Thus, it is suggested to strengthen the insulation of main pipe and change the pipe and the insulation layer if necessary.

The indoor temperature of residents in the near and far-end and high and low-rise of each loop was tested on November 21, 2011, and the test result is shown in Table 8 as follows: 


\begin{tabular}{|c|c|c|c|}
\hline $\mathrm{S} / \mathrm{N}$ & Position & Building No. & $\begin{array}{c}\text { Room } \\
\text { temperature } /{ }^{\circ} \mathrm{C}\end{array}$ \\
\hline 1 & High loop near-end high-rise & $\begin{array}{c}\text { Sunny Winter Garden } 3 \text { \# } \\
1802\end{array}$ & 17.7 \\
\hline 2 & High loop far-end high-rise & $\begin{array}{c}\text { Sunny Winter Garden 1 \# } \\
1502\end{array}$ & 16 \\
\hline 3 & North loop far-end middle-level & $\begin{array}{l}\text { Lang Autumn Garden } 2 \text { \# } \\
301\end{array}$ & 18.8 \\
\hline 4 & North loop middle-end high-rise & $\begin{array}{c}\text { Lang Autumn Garden } 7 \text { \# } \\
503\end{array}$ & 18.1 \\
\hline 5 & South loop far-end low-rise & Summer Garden 4 \# 203 & 17 \\
\hline 6 & South loop near-end low-rise & Summer Garden 3 \# 201 & 19 \\
\hline 7 & High loop near-end low-rise & $\begin{array}{c}\text { Winter Jasmine Garden } 8 \\
\qquad \# 806\end{array}$ & 18.8 \\
\hline 8 & South loop near-end low-rise & $\begin{array}{c}\text { Winter Jasmine Garden } 8 \\
\qquad \# 107\end{array}$ & 17.4 \\
\hline
\end{tabular}

Table 8. Some Residents House Temperature Test

The heat pipe network temperature for proximal end users about $18^{\circ} \mathrm{C}$ and $17{ }^{\circ} \mathrm{C}$ for the near-end residents, which can meet the heating standard requirements basically. There are no overheating window phenomena for residents while there are individual households with water phenomenon without permission during the investigation period in the community.

\section{Energy-Saving Potential Analysis}

\subsection{Boiler Energy-Saving Potential}

According to the on-site operation record check, it is found that in XX Community the exhaust gas temperature of boiler is generally over $160^{\circ} \mathrm{C}$ during the severe cold period, and the exhaust gas temperature of some boilers is 180 ${ }^{\circ} \mathrm{C}$.

The smoke produced by combustion of natural gas boiler contains a great deal of water vapor, latent heat of vaporization and sensible heat of flue gas, and a large amount of flue gas waste heat is discharged into the atmosphere not utilized, causing the heat waste and increasing the consumption of natural gas in the boiler house. Thus, the reasonable recovery and utilization of boiler gas heat and condensing waste heat and the improvement of exchange effect of boiler heat will effectively reduce the heat loss of exhaust gas and increase the boiler efficiency.

2.2 Energy-saving Potential of Transmission and Distribution

Estimate $^{[2]}$ and arrange the pipe network heat loss in all communities according to pipe network operation time and pipe insulation materials and other basic conditions through the on-site investigation, which is shown in Table 9.

\begin{tabular}{|c|c|c|c|c|}
\hline $\begin{array}{c}\text { Boiler house } \\
\text { name }\end{array}$ & $\begin{array}{c}\text { Exhaust gas temperature } \\
\text { in cold period }\left({ }^{\circ} \mathrm{C}\right)\end{array}$ & $\begin{array}{c}\text { Saving } \\
\text { rate }\end{array}$ & $\begin{array}{c}\text { Gas saving volume } \\
\text { (ten thousand } \mathrm{m}^{3} \text { ) }\end{array}$ & $\begin{array}{c}\text { Energy-saving } \\
\text { amount (tce) }\end{array}$ \\
\hline XX Community & $160-175$ & $9 \%$ & 25.25 & 306.64 \\
\hline
\end{tabular}

Table 10. Energy Saving Meter for Flue Gas Condensing Waste Heat Recovery 


\subsubsection{Economic Feasibility Analysis}

The unit-price of natural gas in $X X$ Community is 2.28 Yuan/m3;

Annual energy saving benefits = $25.25 \times 2.28=57.57$ ten thousand yuan/a;

Investment estimation: a total of 8 gas boilers are set in XX Community and 5 gas boilers are in operation during the cold period, a total of 5 sets of condensing waste heat recovery equipment will be installed new pipeline and flue, plus installation, commissioning, operation and maintenance costs, etc., the estimated investment is about 600,000 yuan;

Investment payback period $=60$ $\div 57.57=1.04$ years, the investment payback period of the project is 13 months.

4.2 Hydraulic Balance Adjustment Project

\subsubsection{Project Contents}

It is suggested to install the self-operated flow balancing valve on the backwater main pipe of the heat supply network near-end residential building aiming at these communities where the hydraulic imbalance is obvious.

4.2.2 Project Implementation
Effects

According to relevant experience, the improvement of hydraulic balance of the network will save $10 \%$ of the energy at least. For there is no overheat phenomenon for the near-end users in XX Community, it is possible to save $10 \%$ of the circulating pump power at least by improving the hydraulic balance. The power consumption of the boiler house of XX Community was $490,400 \mathrm{kWh}$ in 2010. The power consumption of about 49,000 kWh has been saved, equivalent to 6 tons of standard coal by improving the hydraulic imbalance phenomenon of pipe networks.

4.2.3 Energy Saving Benefit Calculation

The average unit-price of electricity in XX Community is RMB 0.9 Yuan/kWh;

Annual energy saving benefits $=4.9 \times 0.9=4.41$ ten thousand yuan/a;
Investment estimation: the self-operated flow balance valve equipment is increased, with installation, commissioning and operation and maintenance costs, etc. the estimated investment is about 60,000 yuan;

Investment payback period $=6 \div 4.9=1.2$ years, the investment payback period of the project is 15 months.

4.3 Heating Pipeline Reconstruction Project

\subsubsection{Project Contents}

The foamed polyurethane insulation materials are used to completely replace the aging heating pipes in $X X$ Community, to reduce the network pipe heat loss.

4.3.2 Project Implementation Effects According to the comparison of the energy-saving effect achieved in the heating network reconstruction of Anhua Xili community, check the heat loss before and after the heating network transformation in $X X$ Community at the same time, which is shown in Table 11.

\begin{tabular}{|c|c|c|c|c|c|c|}
\hline \multirow[t]{2}{*}{$\mathrm{S} / \mathrm{N}$} & \multirow[t]{2}{*}{$\begin{array}{c}\text { Community } \\
\text { name }\end{array}$} & \multirow{2}{*}{$\begin{array}{c}\text { Before } \\
\text { renovation } \\
\text { Pipe network } \\
\text { heat loss of \% }\end{array}$} & \multirow{2}{*}{$\begin{array}{c}\text { After } \\
\text { renovation } \\
\text { Pipe network } \\
\text { heat loss of \% }\end{array}$} & $\begin{array}{c}\text { Gas saving } \\
\text { volume }\end{array}$ & $\begin{array}{l}\text { Amount of } \\
\text { saving } \\
\text { electricity }\end{array}$ & $\begin{array}{l}\text { Energy } \\
\text { saving } \\
\text { amount }\end{array}$ \\
\hline & & & & $\begin{array}{c}\text { Ten thousand } \\
\mathrm{m}^{3}\end{array}$ & kWh & tce \\
\hline 1 & $\begin{array}{c}\text { XX } \\
\text { Community }\end{array}$ & 17 & 5 & 33.67 & 58848 & 416.08 \\
\hline
\end{tabular}

Table 11. Comparison of Old Pipeline Network Before and After Transformation 


\subsubsection{Energy Saving Benefit} Calculation

In XX Community, the unit-price of natural gas and electricity is 2.28 yuan/m3 and 0.9 yuan/kWh respectively;

Annual energy saving benefits = $33.67 \times 2.28+5.8848 \times 0.9=82.07$ ten thousand yuan/a;

Investment estimation: for the cost of new pipes, insulation materials, equipment, plus replacement, installation, etc., the estimated investment amount is about 5 million yuan. The financial subsidies are $50 \%$ of the total investment, and the self-financing of 2.5 million yuan.

Investment payback period $=250 \div 82.07=3.05$ years.

\section{Conclusion}

The heating season consumes 2.4798 million $\mathrm{m}^{3}$ of natural gas, the power was 490,400 kWh, equivalent to $3,071.56$ tons of standard coal, and the energy consumption per unit heating area was $9.97 \mathrm{kgce} / \mathrm{m} 2$ from 2010 to 2011 in XX Community through the accounting of energy consumption data of heating system. Its energy consumption index is obviously higher than that of the energy consumption index of other heating area. Analyze the heat source, the pipe network transmission and the end of heating system, it is found that the boiler exhaust gas temperature in this community is high, which leads to greater heat loss of exhaust gas; there are leakage and venting and hydraulic imbalance phenomena due to the aging of heating pipes and insulation layer; meanwhile, the enclosure structure of end residential building envelope poor and indoor heating standard at $18^{\circ} \mathrm{C}$ cause the high heating energy consumption in XX Community.

Put forward the implementation of boiler condensing waste heat recovery, installation of hydraulic balance valve and energy-saving technical proposal for the old pipe network replacement through the analysis of the energy-saving potential in $X X$ Community. It is expected to realize the energy saving 728.72 tce and energy saving benefit of 1.4415 million yuan through three measures for energy saving and technical transformation. Estimated investment cost is 3.16 million yuan.

\section{References}

[1] Energy Efficiency Monitoring and Evaluation of Industrial Boiler System [S] DB11/T 180-2010.(in Chinese)

[2] Heat Loss Test and Insulation Effect Evaluation Method of Heat Insulation Structure of Heating Pipeline [S] CJ/T 140-2001. (in Chinese)

[3] Peifeng Li, Zhihua Ge, Zhengyi Yin, etc.. Model for Energy consumption of heating system and its application [J]. Proceedings of the CSEE, 2013,33 (23):19-28. (in Chinese)
[4] Guirong Wang, Tong Li, Xiufang Liu, etc.. Analysis of energy consumption of central heating system and application of energy-saving measures [J]. Journal of Shandong Jianzhu University, 2012, 27(2):216-219.(in Chinese)

[5] Kuiwei Li, Wenjing Chang. Energy consumption analysis of distributed variable frequency heating system[J], Heating and cooling.2015(7):24-27.(in Chinese)

[6] Jianqi Cao. Study on the water loss in the two pipe network of central heating system[J], Shanxi Architecture,2016,42 (25):117-118.(in Chinese)

[7] Jinwei Li, Jinsheng Liu. Discussion on energy-saving measures of centralized heat-supply system[J], GAS \& HEAT, 2011,31(6):22-25. (in Chinese)

[8] Jianping Zhang. Energy consumption analysis and energy saving measures of residential heating buildings[J], Petrochemical Technology, 2001,8(2):108-111. (in Chinese)

[9] Zhiyong Wang. Flue Gas Heat Loss and Condensing Waste Heat Recovery of Gas Boiler [J]. Gas and Heat, 2010, 30th Volume (6). (in Chinese)

[10] Dong Li. Discussion on Flue Gas Heat Recovery Technology of Gas Boiler [J]. Modern Chemical Industry, 2007, 27th Volume Supplement (2).(in Chinese) 